\title{
EFEKTIVITAS UNIT PRODUKSI SEBAGAI SUMBER BELAJAR KEWIRAUSAHAAN DI SMK KOTA YOGYAKARTA
}

\author{
Yuliansah $^{1}$ dan Aliyah A. Rasyid ${ }^{2}$ \\ ${ }^{1}$ Akademi Manajemen Administrasi Yogyakarta; ${ }^{2}$ Universitas Negeri Yogyakarta \\ E-mail: juli_ansah@yahoo.co.id; aliyahrasyid@gmail.com
}

\begin{abstract}
The objective of this study was to determine how production units can be used effectively as an entreprenuership learning resource to increase the entrepreneurial learning motivation, to clarify the content of the entrepreneurial learning materials and to provide direct experiences for the Vocational High Schools students in Yogyakarta. This study is survey research with quantitative approach. The population of this study were 1.995 students of grade XI and grade XII at 17 Vocational High School in Yogyakarta. 333 students were selected as the sample. Questionnaires and documentation were used for collecting the data. The data was analysed through quantitative descriptive analysis using the Microsoft Excel software. The result of this study indicated that: (1) Production units were effective to increase the intrinsic entrepreneurial learning motivation of the students (2) Production units were ineffective to increase the extrinsic entrepreneurial learning motivation of the students (3) Production units were ineffective to clarify the entrepreneurial learning materials (4) Production units were ineffective to provide direct experiences for the students.
\end{abstract}

Keywords: Direct Experience, Production Units, Learning Materials, Learning Motivation, Learning Resource

ABSTRAK

Penelitian ini bertujuan untuk menemukan tingkat keefektifan penggunaan unit produksi sebagai sumber belajar kewirausahaan dalam hubungannya dengan meningkatkan motivasi belajar kewirausahaan, memperjelas materi pembelajaran kewirausahaan dan memberikan pengalaman langsung bagi siswa SMK di Kota Yogyakarta. Jenis penelitian ini adalah penelitian survei dengan pendekatan kuantitatif. Populasi penelitian ini adalah seluruh siswa kelas XI dan kelas XII pada 17 SMK di Kota Yogyakarta yang berjumlah 1.995 siswa. Sampel dipilih sebanyak 333 orang siswa. Teknik pengumpulan data menggunakan angket dan dokumentasi. Teknik analisis data dilakukan secara deskriptif kuantatif dengan menggunakan software microsoft excel. Hasil penelitian menunjukkan bahwa: (1) unit produksi efektif dalam meningkatkan motivasi intrinsik siswa dalam belajar kewirausahaan SMK di Kota Yogyakarta. (2) unit produksi tidak efektif dalam meningkatkan motivasi ekstrinsik siswa dalam belajar kewirausahaan SMK di Kota Yogyakarta. (3) unit produksi tidak efektif dalam memperjelas materi pembelajaran kewirausahaan SMK di Kota Yogyakarta. (4) unit produksi tidak efektif dalam memberikan pengalaman langsung bagi siswa SMK di Kota Yogyakarta.

Kata Kunci: Materi Pembelajaran, Motivasi Belajar, Pengalaman Langsung, Sumber Belajar, Unit Produksi

\section{PENDAHULUAN}

Era globalisasi telah membawa dampak yang besar terhadap tuntutan kebutuhan dan peningkatan kualitas sumber daya manusia. Sumber daya manusia memainkan peranan yang besar dalam era reformasi ekonomi. Oleh karena itu perlu upaya untuk mempersiapkan kualitas sumber daya manusia Indonesia agar mampu memenangkan persaingan tersebut. Data yang diterbitkan oleh Badan Pusat Statistik tahun
2013 menunjukkan bahwa jumlah pengangguran terbuka mencapai 7.388.737 juta orang sedangkan pada bulan Februari tahun 2014 menurun menjadi 7,2 juta Orang (BPS, 2014) . Jumlah pengangguran di Indonesia yang masih besar mendorong pemerintah untuk terus mencari jalan keluar untuk menekan angka pengangguran tersebut.

Upaya pemerintah tersebut dikemukakan di dalam Rencana Pembangunan Jangka Menengah Nasional (RPJMN) 2010-2014. Bidang 
pendidikan termasuk dalam 11 prioritas nasional yang merupakan implementasi dari Visi dan Misi Pemerintah 2010-2014. Pembangunan bidang pendidikan diarahkan demi tercapainya pertumbuhan ekonomi yang didukung keselarasan antara ketersediaan tenaga terdidik dengan kemampuan: (1) Menciptakan lapangan kerja atau kewirausahaan dan (2) Menjawab tantangan kebutuhan tenaga kerja (Bappenas, 2013: 56).

Salah satu subtansi inti program di bidang pendidikan ini yaitu penataan ulang kurikulum sekolah yang dibagi menjadi kurikulum tingkat nasional, daerah, dan sekolah sehingga dapat mendorong penciptaan hasil didik yang mampu menjawab kebutuhan SDM untuk mendukung pertumbuhan nasional dan daerah dengan memasukkan pendidikan kewirausahaan. Sosialisasi penerapan pendidikan kewirausahaan semakin gencar dilakukan sejak tahun 2010 . Penyelenggaraan pendidikan kewirausahaan sudah diterapkan pada jenjang SMK. Jones dan English (2004: 416) menerangkan bahwa pendidikan kewirausahaan adalah proses menyiapkan individu dengan kemampuan untuk mengenali kesempatan komersial, meningkatkan penghargaan diri, pengetahuan dan keterampilan untuk bertindak terhadap kesempatan komersial tersebut.

Pendidikan kewirausahaan dapat meningkatkan kualitas hidup siswa setelah lulus. Hal tersebut sesuai dengan tujuan pendidikan kejuruan yang dikemukakan oleh Slamet (2011: 189), bahwa tujuan pendidikan vokasi mencakup empat dimensi utama, yaitu: (1) Mengembangkan kualitas dasar manusia yang meliputi kualitas daya pikir, daya qolbu, daya fisik; (2) Mengembangkan kualitas instrumental/kualitas fungsional, yaitu penguasaan ilmu pengetahuan, teknologi, seni, dan olah raga; (3) Memperkuat jati diri sebagai bangsa Indonesia; dan (4) Menjaga kelangsungan hidup dan perkembangan dunia.

Namun sampai dengan saat ini penerapan pendidikan kewirausahaan belum menunjukkan hasil yang menggembirakan. Badan Pusat Statistik merilis data pengangguran terbuka pada bulan Februari tahun 2013 khusus di Daerah
Istimewa Yogyakarta (DIY) yaitu sebanyak 72.494 orang. Tamatan sekolah menengah masih cukup besar dan menempati urutan kedua jumlah pengangguran terbuka di DIY sebesar $33,08 \%$. Peringkat pertama ditempati oleh tamatan universitas atau S1 yaitu sebanyak $38,36 \%$. Selanjutnya disusul oleh tamatan sekolah dasar sebesar 14,63\%, kemudian tamatan Diploma I/ II/ III/ akademi sebesar $11,44 \%$ dan sisanya adalah tamatan sekolah menengah pertama yaitu sebesar $6,46 \%$ (BPS, 2014).

Peran pendidikan kewirausahaan belum mampu meningkatkan lulusan SMK untuk memilih terjun berwirausaha daripada menjadi pengangguran. Dengan memilih berwirausaha seseorang dapat berperan aktif mengurangi pengangguran dengan menyediakan lapangan pekerjaan. Hal tersebut karena pendidikan kewirausahaan baru menyentuh pada tingkatan dasar yaitu pengenalan nilai atau norma dalam wirausaha.

Berdasarkan hasil pra-survei di lapangan masih ditemukan di beberapa sekolah bahwa pembelajaran kewirausahaan hanya bersifat teori dan klasikal saja sehingga menyebabkan siswa menjadi pasif. Padahal seharusnya pembelajaran kewirausahaan harus melatih keaktifan siswa di dalam dan di luar kelas. Konsep pembelajaran dengan melakukan praktik kewirausahaan secara langsung di lingkungan sekolah merupakan cara yang baik untuk melatih siswa dalam berwirausaha. Hal tersebut sesuai dengan konsep pembelajaran kontekstual atau Contextual Teaching and Learning (CTL). Johnson (2012: 35) menyatakan bahwa pembelajaran CTL adalah pembelajaran yang membantu guru mengaitkan antara materi yang diajarkannya dengan situasi dunia nyata siswa dan penerapannya dalam kehidupan.

Penerapan CTL pada pembelajaran kewirausahaan melatih siswa untuk berwirausaha dengan harapan siswa akan mendapatkan value, pengetahuan, dan melatih skill wirausaha. Penyelenggaraan CTL di SMK dilaksanakan melalui penerapan Teaching Factory mengintegrasikan proses pembelajaran untuk meng- 
hasilkan produk maupun jasa yang layak jual untuk menghasilkan nilai tambah untuk sekolah (Direktorat PSMK, 2008: 55). Proses penerapan Teaching Factory dapat dilaksanakan di tempat praktik kewirausahaan.

Salah satu tempat yang dapat dimanfaatkan sebagai tempat praktik siswa untuk latihan berwirausaha adalah unit produksi. Unit produksi merupakan salah satu bentuk sumber belajar di lingkungan sekolah yang sengaja disiapkan sebagai tempat praktik kewirausahaan.

Unit produksi di lingkungan SMK berfungsi sebagai (1) wahana pelatihan berbasis produksi bagi siswa; (2) wahana menumbuhkan dan mengembangkan jiwa wirausaha pada diri siswa SMK; (3) sarana praktik produktif secara langsung bagi siswa; (4) membantu pendanaan untuk pemeliharaan, penambahan fasilitas dan biaya-biaya operasional pendidikan lainnya; (5) menambah semangat kebersamaan, karena dapat menjadi wahana peningkat aktivitas produktif siswa serta memberi 'income' serta peningkatan kesejahteraan warga sekolah (Ditjen PMPTK, 2007:7).

Namun kenyataan di lapangan ternyata banyak unit produksi yang tutup atau tidak aktif sehingga tidak dapat digunakan sebagai sumber belajar bagi siswa. Hal ini dapat dilihat berdasarkan data berikut bahwa dari 172 SMK di Daerah Istimewa Yogyakarta hanya sekitar 10\% yang mempunyai unit produksi aktif, selebihnya tidak berjalan dengan baik atau bahkan hanya nama saja (Usman, 2011: 9). Sedangkan dari 32 SMK yang ada di Kota Yogyakarta hanya 17 SMK atau 53,12\% yang memiliki unit produksi sedangkan sebanyak 15 SMK atau $46,87 \%$ belum memiliki unit produksi atau unit produksi yang ada sudah tutup. Dengan kata lain SMK tersebut tidak memiliki sumber belajar kewirausahaan yang dapat memberikan pengalaman langsung dan simulasi kewirausahaan bagi siswa.

Usaha menjadi sumber belajar yang baik unit produksi harus mendukung keberhasilan dari pendidikan kewirausahaan. Keberhasilan program pendidikan kewirausahaan dapat diketahui melalui pencapaian kriteria oleh siswa yaitu memiliki kemandirian yang tinggi, memiliki kreatifitas yang tinggi, berani mengambil resiko, berorientasi pada tindakan memiliki karakter kepemimpinan yang tinggi, memiliki motivasi yang kuat, memahami konsep-konsep kewirausahaan, memiliki keterampilan/skill berwirausaha di sekolahnya, khususnya mengenai kompetensi kewirausahaan (Mulyani dkk, 2010: 11).

Tetapi pada beberapa unit produksi untuk mencapai hal tersebut sangat sulit. Ada beberapa hal yang menyebabkan hal tersebut yaitu penyelenggaraan unit produksi belum dikelola oleh seorang manajer secara profesional. Dalam pengelolaannya guru tidak dilibatkan secara langsung dalam kegiatan manajemen unit produksi serta siswa hanya dilibatkan sebagai pekerja saja. Selain itu SMK belum mampu memasarkan produk/jasa hasil praktik siswa dengan berbagai alasan, misalnya hasil produksi siswa belum layak jual, tempat yang kurang strategis, sulitnya memasarkan produk/ jasa, kekurangan modal, keterbatasan sarana dan prasarana dan terlalu banyak pesaing.

Dengan berbagai permasalahan di atas sudah tentu salah satu manfaat unit produksi yaitu sebagai sumber belajar tidak dapat berjalan dengan baik. Oleh karena itu perlu dilakukan penelitian tentang efektivitas unit produksi tersebut sebagai sumber belajar kewirausahaan. Hal tersebut berguna bagi SMK yang belum mempunyai unit produksi untuk mendapatkan data yang jelas untuk memutuskan membuat unit produksi di sekolah atau mencari bentuk sumber belajar kewirausahaan yang lain. Berdasarkan uraian di atas, peneliti tertarik untuk mengadakan penelitian tentang "Efektivitas Unit Produksi sebagai Sumber Belajar Kewirausahaan di SMK Kota Yogyakarta”.

\section{METODE}

Penelitian ini merupakan penelitian survei dengan pendekatan kuantitatif. Penelitian survei dilakukan untuk menggambarkan secara sistematis fakta dan karakteristik objek sehingga dapat diketahui efektivitas unit produksi sebagai 
sumber belajar kewirausahaan SMK di Kota Yogyakarta. Pengumpulan data menggunakan angket dan dokumentasi. Analisis data dilakukan dengan teknik deskriptif kuantitatif.

Penelitian ini dilaksanakan pada April s.d Juni 2014. Penelitian ini dilaksanakan di SMKN 1 Yogyakarta, SMKN 3 Yogyakarta, SMKN 3 Yogyakarta, SMKN 4 Yogyakarta, SMKN 5 Yogyakarta, SMKN 6 Yogyakarta, SMKN 7 Yogyakarta. SMK Muhammadiyah 1 Yogyakarta, SMK Muhammadiyah 2 Yogyakarta, SMK Muhammadiyah 3 Yogyakarta, SMK Piri 1 Yogyakarta, SMK Piri 2 Yogyakarta, SMK Bopkri 2 Yogyakarta, SMK Marsudi Luhur 1 Yogyakarta, SMK Koperasi Yogyakarta, SMK Islam Yogyakarta dan SMK Ibu Pawiyatan Tamansiswa.

Populasi dalam penelitian ini adalah siswa yang telah praktik di unit produksi pada 17 SMK. Jumlah seluruh populasi 1.995 siswa. Diambil 333 siswa sebagai sampel penelitian dengan menggunakan proportional random sampling.

Sebelum dilaksanakan penelitian dilakukan dulu penyusunan instrumen berupa angket. Untuk mendapatkan angket yang baik maka dilakukan uji validitas dan reliabilitas (Sukardi, 2003:121). Validitas isi dilakukan secara rasional judgement expert, kemudian dilakukan uji coba validitas konstruk dengan uji coba di lapangan. Reliabilitas instrumen dalam penelitian ini adalah dengan uji statistik Cronbach Alpha $(\alpha)$.

Prosedur penelitian dilakukan dengan melakukan pengumpulan data menggunakan angket dengan skala Likert yang terdiri dari empat pilihan jawaban yaitu: $\mathrm{SS}=$ sangat setuju, $\mathrm{S}=$ =setuju, TS=tidak setuju dan $\mathrm{STS}=$ =sangat tidak setuju. Angket digunakan untuk memperoleh data mengenai peran unit produksi sebagai sumber belajar kewirusahaan. Kemudian data yang sudah diperoleh dianalisis data menggunakan teknik analisis deskriptif kuantitatif yaitu dengan cara menganalisis data dengan statistik deskriptif kemudian mendeskripsikannya dalam bentuk tabel dan grafik. Tabel 1 berikut ini merupakan tingkat kecenderungan variabel.
Tabel 1. Kriteria Kecenderungan Variabel

\begin{tabular}{ll}
\hline Rentang Skor & Interpretasi \\
\hline $\mathrm{X}>(\mathrm{M}+1 \mathrm{SB})$ & Sangat efektif \\
$(\mathrm{M}+1 \mathrm{SB})>\mathrm{X}>\mathrm{M}$ & Efektif \\
$\mathrm{M}>\mathrm{X}>(\mathrm{M}-1 \mathrm{SB})$ & Kurang efektif \\
$\mathrm{X}<(\mathrm{M}-1 \mathrm{SB})$ & Tidak efektif \\
\hline (Mardapi, 2004: 117) &
\end{tabular}

Keterangan:

M : rerata skor keseluruhan siswa

SB : simpangan baku skor keseluruhan siswa

$\mathrm{X}$ : skor yang dicapai siswa

\section{HASIL DAN PEMBAHASAN}

Data dalam penelitian ini diperoleh dengan menggunakan instrumen yang berupa angket dengan penskoran menggunakan skala likert dengan skala 1 sampai dengan 4. Data yang diperoleh selanjutnya dianalisis dengan mengelompokkan item pertanyaan sesuai dengan masing-masing aspek. Kecenderungan keefektifan setiap aspek dilihat dengan menggunakan kategorisasian dengan empat kategori yaitu sangat efektif, efektif, kurang efektif dan tidak efektif. Untuk mencari hasil pengkategorisasian diperlukan nilai skor mean (M) dan standar deviasi (SD) dari masing-masing aspek. Berikut hasil deskripsi data masing-masing aspek disajikan pada Tabel 2.

Tabel 2. Nilai Statistik Deskriptif Kategori Keefektifan Motivasi Instrinsik

\begin{tabular}{lr}
\hline \multicolumn{1}{c}{ Tot } \\
\hline Mean \\
Standard Error & 32,23423 \\
Median & 0,179792 \\
Mode & 32 \\
Standard Deviation & 30 \\
Sample Variance & 3,280891 \\
Skewness & 10,76425 \\
Range & 0,245435 \\
Minimum & 18 \\
Maximum & 22 \\
Sum & 40 \\
Count & 10734 \\
& 333 \\
\hline
\end{tabular}

Berdasarkan nilai batasan yang telah ditentukan pada Tabel 2 di atas, maka dapat 
dibuat tabel skor kriteria sebagaimana ditunjukkan pada Tabel 3 di bawah ini.

Tabel 3. Efektivitas Unit Produksi Meningkatkan Motivasi Instrinsik Belajar Kewirausahaan

\begin{tabular}{llc}
\multicolumn{1}{c}{ Rentang Skor } & Interprestasi & $\mathbf{\%}$ \\
\hline$X \geq 27,49$ & Sangat Efektif & 14,41 \\
$27,49>X \geq 24,76$ & Efektif & 37,54 \\
$24,76>X \geq 22,02$ & Kurang Efektif & 29,13 \\
$X<22,03$ & Tidak Efektif & 18,92 \\
\hline
\end{tabular}

Berdasarkan rentang skor pada Tabel 3 menunjukkan bahwa efektivitas unit produksi dalam meningkatkan motivasi instrikstik belajar kewirausahaan efektif sebesar 51,95\% dan tidak efektif $48,05 \%$. Berdasarkan data tersebut dapat ditarik kesimpulan bahwa unit produksi efektif dalam meningkatkan motivasi instriktik siswa dalam belajar kewirausahaan siswa di SMK Kota Yogyakarta. Sedangkan berdasarkan Tabel 2 nilai skewness bernilai Sk $>0$ sehingga kurva lebih condong ke kiri.

Hasil perbandingan semua distribusi frekuensi efektivitas unit produksi meningkatkan motivasi instriktik siswa disajikan dalam Gambar 1 berikut.

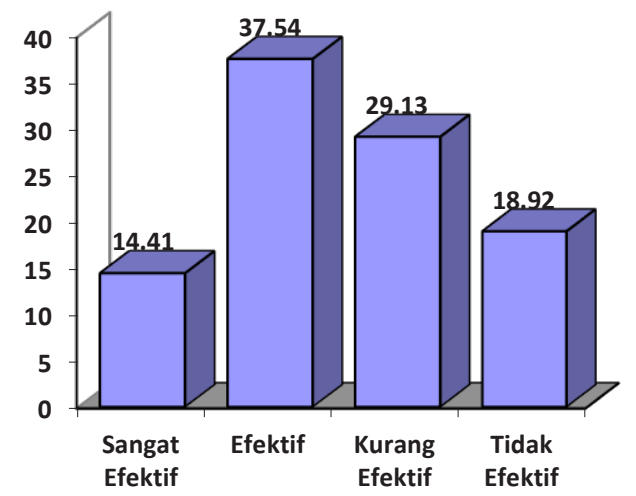

Gambar 1. Efektivitas Unit Produksi Dalam Meningkatkan Motivasi Instrinsik Dalam Belajar Kewirausahaan

Besarnya nilai statistik deskriptif untuk kategori keefektifan motivasi ekstrinsik yang diperoleh siswa adalah sebagaimana disajikan pada Tabel 4 berikut ini.
Tabel 4. Nilai Statistik Deskriptif Kategori Keefektifan Motivasi Ekstrinsik

Tot

\begin{tabular}{lr}
\hline Mean & 35,27327 \\
Standard Error & 0,183881 \\
Median & 35 \\
Mode & 35 \\
Standard Deviation & 3,355508 \\
Sample Variance & 11,25943 \\
Skewness & 0,154123 \\
Range & 19 \\
Minimum & 25 \\
Maximum & 44 \\
Sum & 11746 \\
Count & 333 \\
\hline
\end{tabular}

Berdasarkan nilai batasan yang telah ditentukan pada Tabel 4 di atas, maka dapat dibuat tabel skor kriteria sebagaimana ditunjukkan pada Tabel 5 di bawah ini.

Tabel 5. Efektivitas Unit Produksi dalam Meningkatkan Motivasi Ekstrinsik Belajar Kewirausahaan

\begin{tabular}{llc}
\hline \multicolumn{1}{c}{ Rentang Skor } & Interprestasi & $\mathbf{\%}$ \\
\hline$X \geq 38,62$ & Sangat Efektif & 13,51 \\
$38,62>X \geq 35,27$ & Efektif & 31,53 \\
$35,27>X \geq 31,92$ & Kurang Efektif & 44,14 \\
$X<31,92$ & Tidak Efektif & 10,82 \\
\hline
\end{tabular}

Berdasarkan rentang skor pada Tabel 5 menunjukkan bahwa efektivitas unit produksi dalam meningkatkan motivasi ekstrinsik belajar kewirausahaan di SMK Kota Yogyakarta tidak efektif sebesar 54,96\% sedangkan efektif $44,14 \%$. Berdasarkan data tersebut dapat ditarik kesimpulan bahwa unit produksi kurang efektif dalam meningkatkan motivasi ekstrinsik belajar kewirausahaan siswa di SMK Kota Yogyakarta. Sedangkan berdasarkan tabel 4 nilai skewness bernilai Sk $>0$ sehingga kurva lebih condong ke kiri. Hasil perbandingan semua distribusi frekuensi efektivitas unit produksi meningkat motivasi ekstrinsik siswa disajikan dalam Gambar 2 berikut: 


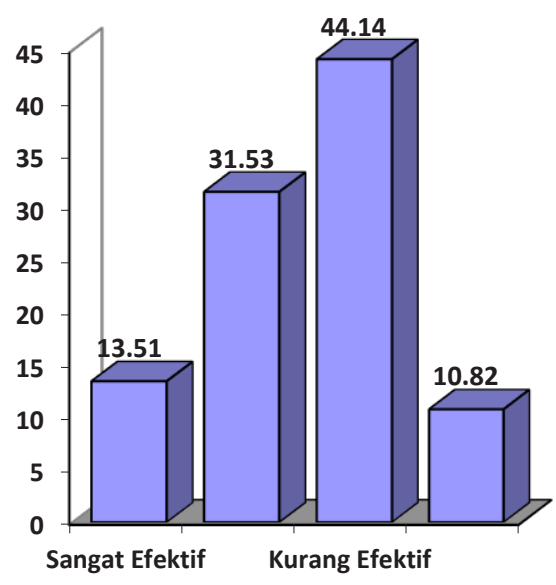

Gambar 2. Efektivitas Unit Produksi dalam Meningkatkan Motivasi Ekstrinsik dalam Belajar Kewirausahaan

Besarnya nilai statistik deskriptif untuk kategori keefektifan materi pembelajaran kewirusahaan adalah sebagaimana disajikan pada Tabel 6 berikut ini.

Tabel 6. Nilai Statistik Deskriptif Kategori Keefektifan Materi Pembelajaran Kewirausahaan

\begin{tabular}{lr}
\hline \multicolumn{1}{c}{ Tot } \\
\hline Mean & 30,26126 \\
Standard Error & 0,238682 \\
Median & 30 \\
Mode & 30 \\
Standard Deviation & 4,355536 \\
Sample Variance & 18,97069 \\
Skewness & 2,02565 \\
Range & 52 \\
Minimum & 17 \\
Maximum & 69 \\
Sum & 10077 \\
Count & 333 \\
\hline
\end{tabular}

Berdasarkan nilai batasan yang telah ditentukan pada Tabel 6 di atas, maka dapat dibuat tabel skor kriteria keefektifan materi pembelajaran kewirusahaan sebagaiman ditunjukkan ada Tabel 7 di bawah ini.
Tabel 7. Efektivitas Unit Produksi Memperjelas Materi Pembelajaran Kewirausahaan

\begin{tabular}{clc}
\hline Rentang Skor & Interprestasi & $\mathbf{\%}$ \\
\hline$X \geq 34,62$ & Sangat Efektif & 11,71 \\
$34,62>X \geq 30,26$ & Efektif & 28,83 \\
$30,26>X \geq 25,91$ & Kurang Efektif & 48,35 \\
$X<25,91$ & Tidak Efektif & 11,11 \\
\hline
\end{tabular}

Berdasarkan rentang skor pada Tabel 7 menunjukkan bahwa efektivitas unit produksi dalam memperjelas materi pembelajaran kewirausahaan di SMK Kota Yogyakarta tidak efektif sebesar $59,46 \%$ dan efektif sebesar $40,54 \%$. Berdasarkan data tersebut dapat ditarik kesimpulan bahwa unit produksi tidak efektif dalam memperjelas materi pembelajaran kewirausahaan di SMK Kota Yogyakarta. Sedangkan berdasarkan Tabel 6 nilai skewness bernilai $\mathrm{Sk}>0$ sehingga kurva lebih condong ke kiri.

Hasil perbandingan semua distribusi frekuensi efektivitas unit produksi memperjelas materi pembelajaran kewirausahaan disajikan dalam Gambar 3 berikut:

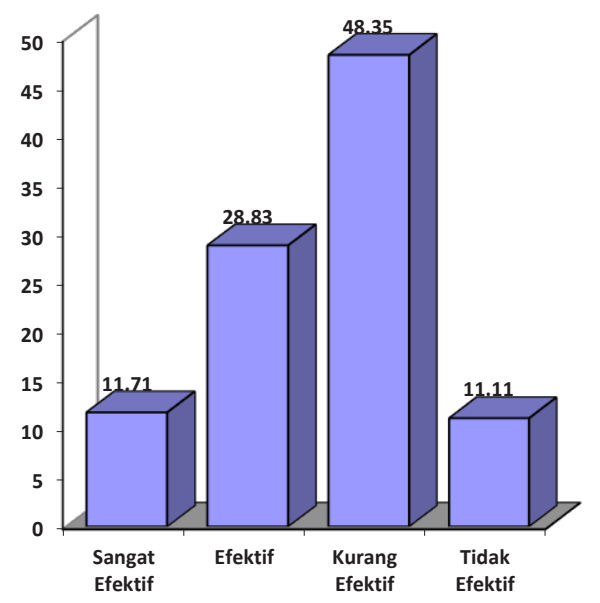

Gambar 3. Efektivitas Unit Produksi Dalam Memperjelas Materi Pembelajaran Kewirausahaan

Besarnya nilai statistik deskriptif untuk kategori keefektifan unit produksi adalah sebagaimana disajikan pada Tabel 8 berikut ini. 
Tabel 8. Nilai Statistik Deskriptif Kategori Keefektifan Unit Produksi

\begin{tabular}{lr}
\hline \multicolumn{1}{c}{ Tot } \\
\hline Mean & 32,23423 \\
Standard Error & 0,179792 \\
Median & 32 \\
Mode & 30 \\
Standard Deviation & 3,280891 \\
Sample Variance & 10,76425 \\
Skewness & 0,245435 \\
Range & 18 \\
Minimum & 22 \\
Maximum & 40 \\
Sum & 10734 \\
Count & 333 \\
\hline
\end{tabular}

Berdasarkan nilai batasan yang telah ditentukan pada Tabel 8 di atas, maka dapat dibuat tabel skor kriteria sebagaimana disajikan pada Tabel 9 di bawah ini.

Tabel 9. Efektivitas Unit Produksi Memberikan Pengalaman langsung

\begin{tabular}{clc}
\hline Rentang Skor & Interprestasi & $\mathbf{\%}$ \\
\hline$X \geq 35,51$ & Sangat Efektif & 14,41 \\
$35,51>X \geq 32,23$ & Efektif & 31,53 \\
$32,23>X \geq 28,95$ & Kurang Efektif & 45,05 \\
$X<28,95$ & Tidak Efektif & 9,01 \\
\hline
\end{tabular}

Berdasarkan tabel 9 menunjukkan bahwa efektivitas unit produksi dalam memberikan pengalaman langsung di SMK Kota Yogyakarta tidak efektif sebesar $54,06 \%$ dan efektif sebesar 45,94\%. Berdasarkan data tersebut dapat ditarik kesimpulan bahwa unit produksi tidak efektif dalam memberikan pengalaman langsung bagi siswa di SMK Kota Yogyakarta. Sedangkan berdasarkan tabel 8 nilai skewness bernilai Sk $>$ 0 sehingga kurva lebih condong ke kiri.

Hasil perbandingan semua distribusi frekuensi efektivitas unit produksi memberikan pengalaman langsung disajikan dalam Gambar 4 berikut.

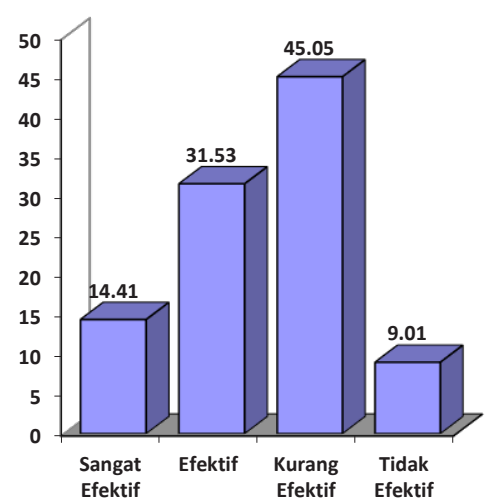

\section{Gambar 4. Efektivitas Unit Produksi Memberikan Pengalaman langsung}

Analisis deskriptif unit produksi sebagai sumber belajar yakni dapat meningkatkan motivasi instrintik, motivasi ekstrinstik, memperjelas materi pembelajaran dan memberikan pengalaman langsung. Adapun rangkuman hasil deskripsi data efektivitas unit produksi adalah sebagaimana disajikan ada Tabel 10 berikut.

Tabel 10. Kategori Hasil Setiap Variabel

\begin{tabular}{lcc}
\hline \multicolumn{1}{c}{ Variabel } & $\mathbf{\%}$ & Kategori \\
\hline $\begin{array}{l}\text { Meningkatkan } \\
\text { motivasi instrintik }\end{array}$ & 51,95 & Efektif \\
\hline $\begin{array}{l}\text { Meningkatkan } \\
\text { motivasi ekstrinsik }\end{array}$ & 54,9 & Tidak \\
\hline $\begin{array}{l}\text { Memperjelas materi } \\
\text { pembelajaran }\end{array}$ & 59,46 & Tidak \\
\hline $\begin{array}{l}\text { Memberikan } \\
\text { pengalaman }\end{array}$ & 54,0 & Efektif \\
langsung & & Tidak \\
\hline
\end{tabular}

Tabel 10 di atas menunjukkan bahwa unit produksi hanya efektif meningkatkan motivasi instrintik siswa dalam belajar kewirausahaan yaitu sebesar $51,95 \%$, sedangkan tidak efektif dalam meningkatkan motivasi ekstrinsik yaitu sebesar 54,96\%, memperjelas materi kewirausahaan yaitu sebesar 59,46\% dan memberikan pengalaman langsung yaitu sebesar $54,06 \%$.

Berdasarkan data tersebut dapat disimpulkan bahwa pertama, unit produksi efektif dalam meningkatkan motivasi instrintik siswa dalam belajar kewirausahaan. Secara keseluruhan unit produksi pada SMK di Kota Yogya- 
karta efektif dalam meningkatkan motivasi instrinstik belajar kewirausahaan.

Ada beberapa hal yang dapat menjadi faktor hal tersebut terjadi yaitu pertama, SMK negeri maupun swasta sudah mempunyai unit produksi sebagai salah satu sumber belajar. Kegiatan praktik yang dilaksanakan di unit produksi merupakan salah satu kegiatan pembelajaran yang juga dilakukan oleh siswa selain mendapatkan teori di kelas. Konsep pembelajaran kewirausahaan di unit produksi didesain agar siswa dapat belajar kewirausahaan secara langsung. Selain mereka dapat belajar kewirausahaan secara langsung mereka juga akan mendapatkan penghasilan dari produk barang/ jasa yang mereka hasilkan. Penghasilan atas produksi barang/jasa ini membuat siswa tertarik akan pembelajaran kewirausahaan.

Kedua, unit produksi yang telah berjalan dapat memberikan penghasilan dari penjualan barang/jasa kepada siswa yang praktek. Siswa yang belum pernah melaksanakan praktek di unit produksi akan tumbuh keinginan untuk praktek dan belajar kewirausahaan karena melihat siswa yang praktek di unit produksi mendapatkan penghasilan tambahan. Walaupun tidak semua siswa mendapatkannya, tetapi kesempatan untuk mendapatkan penghasilan tambahan terbuka luas bagi siswa yang ingin praktik di unit produksi. Ketiga, pembelajaran kewirausahaan yang menekankan pada pentingnya action atau praktik agar dapat menjadi seorang wirausaha yang sukses dapat meningkatkan motivasi instrinstik siswa untuk lebih serius belajar kewirausahaan.

Ketiga, unit produksi tidak efektif dalam meningkatkan motivasi ekstrinsik siswa belajar kewirausahaan. Unit produksi sebagai tempat praktek kewirausahaan seharusnya mampu meningkatkan motivasi ekstrinstik siswa dalam belajar kewirausahaan. Faktor guru kewirausahaan sendiri yang kurang dapat meningkatkan motivasi belajar peserta didik. Pada SMK negeri kelompok seni, pariwisata, bisnis dan manajemen guru kewirausahaan biasanya bekerjasama dengan pengolah unit produksi untuk menempatkan siswanya praktik kewirausahaan di unit produksi, sehingga dapat tercipta hubungan yang sinergis antara pengola unit produksi dengan guru kewirusahaan.

Sedangkan pada SMK negeri kelompok teknik dan swasta unit produksi biasanya dikelolah oleh guru yang mengajar mata pembelajaran produktif saja. Misalnya di SMK teknik guru yang menjadi pengola unit produksi yaitu guru teknik. Berdasarkan pengamatan di lapangan tidak ada kerjasama antara guru kewirausahaan dengan guru yang mengelola unit produksi jurusan. Sehingga cenderung siswa yang praktik kewirausahaan hanya sekedar dibiarkan untuk praktik saja tanpa dibimbing oleh guru kewirausahaan sendiri secara maksimal karena kurangnya kerja sama antara guru pengola unit produksi dengan guru mata pelajaran kewirausahaan.

Selain itu faktor unit produksi itu sendiri yang mempunyai jam operasional terbatas membuat kondisi unit produksi menjadi terbatas jumlah penjualan jasa/barang. Hal tersebut yang membuat unit produksi menjadi sulit dalam menjual barang/jasa. Dengan penjualan yang sepi akan berdampak kepada motivasi ekstrinstik siswa yang praktik kewirusahaan di unit produksi tersebut.

Keempat, unit produksi tidak efektif dalam memperjelas materi pembelajaran kewirausahaan. Dalam pelaksanaan praktik kewirausahaan unit produksi berperan dalam memberikan kejelasan materi yang didapatkan di kelas. Apakah pada saat pembelajaran materi yang diberikan sesuai dengan yang ada di lapangan atau unit produksi. Beberapa materi yang dapat diperjelas melalui unit produksi sebagai sumber belajar yaitu cara menjual barang atau jasa, cara bernegosiasi dengan konsumen, membuat iklan, membuat laporan transaksi barang atau jasa dan membuat laporan keuangan. Setelah siswa mendapatkan materi pembelajaran tersebut mereka langsung diberikan kesempatan untuk mempraktikkan materi tersebut.

Kenyataan di lapangan hanya unit produksi berbentuk koperasi, minimarket, bengkel service yang mampu bersentuhan langsung 
dengan konsumen. Sedangkan unit produksi yang lain terutama pada SMK teknik konsumen yang memesan langsung bertemu dengan guru mata pembelajaran produktif/pengolah unit produksi. Hal tersebut mengakibatkan siswa tidak pernah melakukan pelayanan secara langsung terhadap konsumen. Sedangkan pada unit produksi yang berbentuk koperasi, minimarket serta bengkel service siswa diberikan kesempatan untuk melayani konsumen secara langsung dapat pula bernegoisasi masalah harga walaupun pada akhirnya tetap akan melibatkan pengola unit produksi apabila berkaitan dengan masalah negosiasi harga jual barang.

Sedangkan dalam pembuatan iklan, laporan transaksi barang dan jasa serta laporan keuangan siswa disemua unit produksi jarang diberikan kesempatan untuk dapat melaksanakan kegiatan tersebut. Hal utama yang menjadikan dasar pembatasan kegiatan praktik tersebut adalah untuk menekan jumlah kesalahan yang dilakukan oleh siswa. Apabila siswa diberikan keluluasaan praktik secara mandiri bukan tidak mungkin terjadi kesalahan fatal. Kesalahan fatal tersebut akan berdampak buruk bagi unit produksi karena menyangkut pelayanan kepada konsumen dan pembuatan laporan keuangan. Apabila terjadi kesalahan dalam membuat iklan, laporan transaksi barang dan jasa serta laporan keuangan akan berdampak buruk bagi evaluasi unit produksi itu sendiri. Hal tersebut dikarenakan laporan tersebut digunakan sebagai bentuk pertanggung jawaban pengolah serta sebagai indikator apakah unit produksi tersebut mendapatkan keuntungan atau mengalami kerugian.

Selain itu pada beberapa SMK teknik unit produksi hanya dijadikan tempat persiapan bagi siswa sebelum melaksanakan kegiatan prakerin sehingga siswa yang praktik di unit produksi hanya sebentar saja. Kurangnya koordinasi antara guru kewirausahaan, pengolah unit produksi dan penanggung jawab unit produksi dalam hal ini guru mata pembelajaran produktif menjadikan unit produksi bukan lagi tempat praktek kewirausahaan tetapi hanya sebatas tempat untuk mempersiapkan peserta didik untuk melakukan kegitan prakerin. Sehingga siswa tidak diberikan kesempatan untuk melaksanakan praktek dalam jangka waktu yang lama.

Kelima, unit produksi tidak efektif dalam memberikan pengalaman langsung tentang kewirausahaan bagi siswa. Unit produksi merupakan salah satu wadah praktik kewirausahaan yang tujuannya untuk memberikan pengalaman tentang kewirausahaan secara langsung kepada siswa. Dalam unit produksi peserta didik melakukan aktivitas kewirausahaan sehingga siswa mendapatkan pengalaman langsung. Sedangkan didapat hasil dalam penelitian ini bahwa secara keseluruhan unit produksi kurang efektif dalam memberikan pengalaman langsung bagi siswa yang praktik. Hal tersebut dikarenakan kurangnya kesempatan yang diberikan pengolah unit produksi kepada siswa yang praktik untuk dapat melakukan beberapa hal di atas. Padahal diharapkan setelah siswa praktik di unit produksi mereka memperoleh pengalaman langsung.

Kebanyakan siswa yang praktik di unit produksi biasanya hanya melayani pelanggan, memproduksi barang atau jasa, menata produk atau display produk pada unit produksi yang berbentuk koperasi, minimarket. Sedangkan pada unit produksi bengkel dan jasa boga siswa biasanya hanya diberikan kesempatan untuk memproduksi barang tanpa bisa memasarkannya secara langsung. Siswa yang praktik tidak pernah diberikan kesempatan untuk bernegoisasi langsung dengan pelanggan, membuat laporan transaksi barang atau jasa dan membuat laporan keuangan. Hal tersebut dilakukan oleh langsung oleh pengola unit produksi ataupun guru mata pembelajaran produktif.

Hal tersebut dilakukan untuk mengurangi risiko kesalahan fatal apabila diserahkan kepada siswa yang praktik. Karena beberapa kegiatan di atas merupakan kegiatan yang penting misalnya membuat laporan barang atau jasa dan membuat laporan keuangan. Membuat laporan tersebut membutuhkan waktu yang lama dan biasanya dilakukan sebulan sekali. Sedangkan siswa praktik di unit produksi hanya mengandalkan 
jam sekolah saja sehingga mereka bekerja biasanya hanya pada jam istirahat atau sepulang sekolah. Padahal untuk membuat laporan tersebut membutuhkan waktu yang lama, ketelitian dan kecermatan. Kesalahan sedikit dapat menyebabkan informasi yang diberikan kepada sekolah akan salah. Laporan yang salah akan dapat menyebabkan pengambilan keputusan yang salah pula. Oleh karena itu sebagian besar sekolah yang mempunyai unit produksi membatasi keterlibatan langsung siswa yang praktik hanya pada hal-hal yang tidak menyebabkan kesalahan yang fatal bagi unit produksi. Hal yang menyangkut pembuatan laporan biasanya diambil alih oleh pengolah unit produksi langsung ataupun guru yang bertanggung jawab terhadap unit produksi tersebut.

Selain hal di atas faktor lain yang menyebabkan unit produksi kurang efektif memberikan pengalaman kewirausahaan secara langsung kepada siswa adalah kurang lakunya unit produksi itu sendiri. Beberapa unit produksi yang ada di SMK negeri dan swasta sebagian besar produk barang atau jasa yang mereka produksi penjualannya sangat sedikit. Misalnya unit produksi jasa service kendaraan ringan, jasa boga, jasa service elektronik, jasa multimedia dan koperasi letaknya kurang strategis sehingga yang membeli ataupun yang menggunakan jasa tersebut adalah pihak internal sekolah saja. Hal tersebut menyebabkan kegiatan di unit produksi sebagian besar sepi.

Tetapi ada beberapa unit produksi yang memang sudah lebih baik kondisinya seperti Business Centre milik SMK 7 Yogyakarta. Karena posisinya sangat strategis dan dekat dengan hotel, toserba dan pusat penjualan tiket di Bussiness Centre menghasilkan penjualan yang bagus. Hal tersebut ditambah dengan lokasi toserba yang berada di depan area sekolah sehingga masyarakat sekitar yang ingin berbelanja lebih mudah tanpa harus menggangu aktivitas utama sekolah yaitu kegiatan belajar mengajar.

\section{SIMPULAN}

Berdasarkan uraian tersebut, simpulan dari penelitian ini adalah sebagai berikut: (1) Unit produksi efektif dalam meningkatkan motivasi intrinsik siswa dalam belajar kewirausahaan SMK di Kota Yogyakarta. (2) Unit produksi tidak efektif dalam meningkatkan motivasi ekstrinsik siswa dalam belajar kewirausahaan SMK di Kota Yogyakarta. (3) Unit produksi tidak efektif dalam memperjelas materi pembelajaran kewirausahaan SMK di Kota Yogyakarta. (4) Unit produksi tidak efektif dalam memberikan pengalaman langsung bagi siswa SMK di Kota Yogyakarta.

Berdasarkan simpulan di atas, maka saran dari penelitian ini adalah sebagai berikut.

(1) Dinas Pendidikan Kota Yogyakarta hendaknya memberikan bantuan fasilitas unit produksi kepada SMK, agar pelatihan kewirausahaan dapat berjalan lancar dan produktif. (2) Kepala SMK Kota Yogyakarta hendaknya menyediakan alokasi jam operasional dan praktik kerja di unit produksi jangan hanya sampai jam pulang sekolah agar meningkatkan tingkat akses konsumen yang ingin membeli barang/ jasa. (3) Guru kewirausahaan hendaknya membuat jadwal bagi siswa yang akan praktek di unit produksi secara berkala sehingga lebih teratur. (4) Pengola unit produksi hendaknya membimbing, mengarahkan siswa yang praktek di unit produksi agar dapat melaksanakan kegiatan praktek sesuai dengan materi yang didapatkan di kelas

\section{DAFTAR RUJUKAN}

AECT. 2004. The Definiton of Educational Technology. Washington DC: AECT

Badan Penelitian dan Pengembangan Pusat Kurikulum. 2010. Pengembangan Pendidikan Kewirausahaan. Jakarta: Kementerian Pendidikan Nasional

Badan Pusat Statistik. 2014. Perkembangan Beberapa Indikator Utama SosialEkonomi Indonesia Februari 2014. Jakarta: Badan Pusat Statistik 
Badan Pusat Statistik. 2014. Statistik Ketenagakerjaan Daerah Istimewa Yogyakarta 2013-2014. Yogyakarta: Badan Pusat Statistik Propinsi Daerah Istimewa Yogyakarta

BAPPENAS. 2013. Evaluasi Paruh Waktu RPJMN 2010-2014. Jakarta: BAPPENAS

Berg, G.A. 2002. Why Distance learning? Higher Education Administrative Practices. Amerika: Praeger Publisher

Depdiknas. 2008. Panduan Pengembangan Materi Pembelajaran. Jakarta: Direktorat Jenderal Pendidikan Dasar dan Menengah. Direktorat Pembinaan Sekolah Menengah Atas.

Direktorat PSMK. 2008. Kewirausahaan dalam kurikulam SMK. Makalah disajikan dalam Seminar Nasional Wirausaha Kuliner, di Jurusan Teknologi Industri, Fakultas Teknik, Universitas Negeri Malang

Johnson, E.B. 2012. Contextual Teaching \& Learning (CTL) Terjemahan Ibnu Setiawan. California: Corwin Press.inch.

Jones, C \& English, J. 2004. A Contemporary Approach To Entrepreneurship Education. Education + Training. 46, 416-423
Mardapi, D. 2004. Penyusunan Tes Hasil Belajar. Yogyakarta: Program Pascasarjana Universitas Negeri Yogyakarta

Mulyani, E. dkk (2010). Pengembangan Pendidikan Kewirausahaan. Jakarta: Pusat Kurikulum, Badan Penelitian dan Pengembangan, Kementerian Pendidikan Nasional.

Slamet, P. H. 2011. Peran Pendidikan Vokasi Dalam Pembangunan Ekonomi. Cakrawala Pendidikan. 2, 189-203

Sukardi. 2012. Metodologi Penelitian Pendidikan Kompetensi dan Praktiknya. Jakarta: Bumi Aksara

Usman, T. 2011. Model Unit Produksi SMK di Daerah Istimewa Yogyakarta. Studi Kasus di SMKN 2 Pengasih Kulon Progo. Disertasi Doktor, tidak diterbitkan. Yogyakarta: Universitas Negeri Yogyakarta 